\title{
The Collapse of Indigenous Socio-political Systems in the Horn of Africa: The Case D'irasha Community in South Western Ethiopia
}

\author{
Firew Tesfaye Odayte \\ Arba Minch University, Social and Behavioural Research Unit, Arba Minch, Ethiopia
}

Email address:

firewt@yahoo.com,otayte@Gmail.com

\section{To cite this article:}

Firew Tesfaye Odayte. The Collapse of Indigenous Socio-political Systems in the Horn of Africa: The Case D'irasha Community in South Western Ethiopia. International Journal of Science, Technology and Society. Vol. 5, No. 4, 2017, pp. 97-106. doi: $10.11648 /$ j.ijsts.20170504.17

Received: July 13, 2016; Accepted: January 25, 2017; Published: July 10, 2017

\begin{abstract}
The central goal of this study is to expose the Process of the dismantling of indigenous socio-political systems in South Western Ethiopia of the horn of Africa with particular reference the D'irasha community. The study examines the way the Abyssinians political and cultural hegemony destructed social and political values of indigenous communities in the region. It also tries to see the role of other factors like the Italian occupation, the missionary activities and the adherence of socialism by Ethiopian state as contributors. Furthermore, the paper investigates the emergence of the D'irasha as unique ethnic community and the nature of their socio-political organization.
\end{abstract}

Keywords: Socio-political System, Indigenous, Abyssinia, Hegemony, Identity

\section{Introduction}

Pre-colonial African societies have had their own sociopolitical systems of governance and institutions to regulate the relationship among their people. However, colonialism and the subsequent social changes largely affected these systems which finally led many of them to collapse in many parts of the continent. Even though, Ethiopia is one of the states in Africa immune from western imperialist colonization its Abyssinian Kingdom conquered and imposed its political and cultural hegemony upon many of east African independent kingdoms, chiefdoms and communities. According to Asmerom, the military expansion of Menelik II (r.1889-1913) to the Southern territories which was referred as Hager maqnat or Masgeber connote similar idea with the "the civilizing mission" of western imperialists. Literary, in Amharic (1), maqnat implies "to civilize"; the Amharic equivalent of colony, qegn hager, is believed to have been

${ }^{1}$ Amharic is the most widely spoken language in Ethiopia today. Originally it was the language spoken by the Abyssinian and expanded to other territories of the country with the expansion of the Abyssinian kingdom in the horn of Africa. derived from hager maqnat. On the other hand masgeber implies "to subjugate" or to force someone to become loyal. Thus, what the Abyssinian Kingdom of Ethiopia has done was more or less similar to what the European imperialists did. Because "colonizer is colonizer be it African or European (Asmarom, 2006)".

The D'irasha community is one of the ethnic communities residing in south western Ethiopia of the horn of Africa. Linguistically and culturally they belong to the low land eastern Cushitic family sharing linguistic and cultural resemblance with the Oromo and Somali people of the horn. There are in fact Omotic cultural elements diffused to their way of life from the neighboring groups like the Gamo and Zayase. The people call themselves D'irasha though few literatures and pre-1991 state documents mention them as Gidole and Gardulla. Their language is called D'irayta while the people call their land D'irashe, to mean the land of the people who speak D'irayta (Wonwosen, 2006). This people were incorporated to the Abyssinian Empire of Ethiopia towards the end of $19^{\text {th }}$ during the partition for Africa and in a similar fashion. Since then they were under the Abyssinian cultural and political hegemony and were victims of the losing many of the aspects of their cultural values. 
Therefore, this paper tries to expose how the sociopolitical systems of indigenous communities in the horn of Africa deteriorated by an African conqueror and the imposition the subsequent hegemony with particular emphasis to the D'irasha. The major objective of the paper is to clearly indicate how the imposition of alien political and religious systems by the Abyssinians gradually altered the indigenous one. In fact, the article also tries to examine the contribution of other external factors like the brief Italian occupation (1936-1941) and the coming of the Norwegian Lutheran Mission to the region. Furthermore, an assessment was made about the impact of the introduction socialism as the ideology of the state and present condition of the indigenous socio-political systems in the restructuring of the sate along ethnic lines since 1991.

\section{Study Area and Methodology}

\subsection{Introducing the Study Area}

The D'irasha people are one of the ethno-linguistic groups in Southern Nations, Nationalities and Peoples Regional State of Federal State of Ethiopia. Administratively they are found in Derashe District of Segan Area Peoples Administrative Zone. Naturally, they are located between Lake Chamo and Gardulla Mountain (2600m asl). They share different aspects of culture and show some kind clan resemblances with the adjoining communities residing between Sagen and Woyto rivers in southwestern Ethiopia. These include the Alle (formerly Dobasse), Mosiya, Konso, Kusume and Mashole.

The present political and economic headquarter of D'irashe District is Gidole town. It was established by Italians during their brief occupation of Ethiopia (1936-1941) and remained as one the oldest town in the region. Geographically Gidole is located at 37.30' East and 5.30' North, latitude and longitude respectively. Gidole is $550 \mathrm{~km}$ away from the Federal Capital Addis Ababa and $50 \mathrm{~km}$ away from the nearby town Arba Minch. Demographically, based on statistical progression of the census result of 2007 the total population of the D'irasha is estimated around 141,181, out of which $51 \%$ are women. Out of the total population only $10 \%$ are living in urban areas. The average population density is 117 person $/ \mathrm{sqkm}^{(2)}$.

Agriculture (crop farming and livestock production) is the major source of livelihood for the D'irasha. Their territory is divided in to three agro-ecological sections: highland (Komole), middle latitude (Albata) and low land (Soyo). In the highland, which is part of the Gardulla Mountain, they produce barley, pea, bean, vegetables and largely enset. In the middle latitude they mainly produce cash crops like coffee and chat. In the low land, where the major farmland is located, they produce cereals like sorghum (main crop), maize and teff. The D'irasha's are hardworking people who stay in their farmlands throughout the year and are source of

\footnotetext{
${ }^{2}$ Central Statistics Authority of Ethiopia 2015 report
}

cereals for major towns in southern Ethiopia. Livestock production is also significantly means of livelihood (Firew, 2011).

\subsection{Methods and Procedures}

The study was designed qualitatively as a cultural study and ethnographic research techniques were largely employed. Purposive sampling was used in order find informants with detailed knowledge of the subject under study. Field observation was made for two months in 2011. Primary data was collected from local elders through in-depth unstructured interviews, focus group discussions and observation. Though primary data was very scant specifically about the D'irasha, review was made to the very few literatures related to the subject. The data obtained from different sources was filtered and organized for triangulation and systematic analysis was made appropriately. The researcher was born among the D'irasha in Gidole in 1980 and was there until 1999. He also served as a primary school teacher and education programs team coordinator till 2008. Ethical issues were also observed properly.

\subsection{Objective}

The main goal of this study was to methodically indicate the process through which indigenous socio-political systems collapsed in the horn of Africa with special emphasis on the D'irasha community.

\section{Results and Discussions}

\subsection{The Genesis of the D'irasha Ethnic Identity}

Like many of the communities in Africa, the people of D'irasha have their own myth to explain social and natural phenomena's in their surroundings. The following is one of the mythological explanations about the source of ethnolinguistic diversity in their adjacent areas:

"The earth was plaint at the beginning and people speak the same language. Then Moha [the sky God] created mountains and valleys in order to give separate habitat for people. Then he made people living in different places, beyond mountains and valleys, speak different language. It was due to this that we are called D'irasha because we speak D'irayta", (3)

Based on this myth, the people consider language as a core element that differentiates them from people around them. In fact, the area situated within borders of Lake Chamo, and Sagen-Woyto rivers is characterized by high degree of ethnolinguistic diversity. In this relatively smaller territory there are six groups who claim to be distinct socially and linguistically. These include the Konso, D'irasha, Mashole, Kusme (Gato), Mossie (Bussa) and Dobase (Alle) (Black,

\footnotetext{
${ }^{3}$ This was an explanation by Karite Kindhila who was at age of 102 in 2011 during my field work for my MA thesis in Kermoha village of D'irashe
} 
1973 and Hallpike, 1972). (4) Backed by this truth on the ground, the D'irasha associate their identity with their language (D'rayta). Their ethnic, social and cultural identity is also attached to their indigenous socio-political organization. D'irashaness is explained in the unity of the nine clans under one Dha'ama, who is assumed to have a gift of "making rain and blessing crops and animals". Their identity is also linked with their unique agricultural practices of Targa, Potaya, Polota and the use of Pawra that they assume differentiates them from other social groups in the region.

The genesis of the emergence of the D'irasha as apolitically organized society is related to the folktale of Dha'ama ${ }^{(5)} \mathrm{Ka}$ 'ana. Among the nine clans of D'irasha some of them believed to have migrated from a place named Sabar through Liben (Somali/Borena) the rest claim to be in the land since time immemorial. The clan to whom Dha'ama $\mathrm{Ka}$ 'ana belongs is one of those who claim to be there. According to the tradition this clan which is called Elayta, emerged from the soil of D'irashe. They are assumed to be the first settlers the land. Economically they were agropastoralists. The crop they mainly produced was called $K a$ 'ata. From the emic explanation of the people Ka'ata is teff or teff like cereal. Dha'ama Ka'ana had the gift of blessing crop and making rain. The folktale goes as follows: (6)

"Once up on a time Dha'ama Ka'ana ordered his people to kill all elders in the land. Since he was the sole rain maker and the one who blesses crops and animals, his orders were highly respected. Because of this the people started to kill all elders. While the killing was taking place, one elder pleaded the killer's not to kill him convincing them that he would teach them wisdom. They listened hidden him in a bee house placed in a kitchen place called qishat. After checking all the elders had been killed, Ka'ana mixed up Ka'ata (the teff like cereal) with dust and ordered his people to collect it and fill a container known as Ungula. This was very difficult for the people, because it is impossible to collect Ka'ata from dust. By this time the people went to the elder to ask for solution. Then he advised them to come with small piece of the Ka'ata grain in their hands from their houses and fill the container; clear up the area and tell the Dha'ama as if they have collected it. When the people did accordingly the Dha'ama suspected that the people might have not killed all the elders. When he asked about it, however, they confirmed that no elder is left alive.

For the second time, he ordered his people to bring a cow that urinate milk. The people went to the elder. He advised them to take a cow and keep it away from water for a week

\footnotetext{
${ }^{4}$ According to my observation there is strong linguistic and cultural resemblance among the communities in the region despite their claim of separate identity.

${ }^{5}$ Dha'ama is a person who is highly respected among the D'irasha, he is considered as a father the whole community, and who is considered to have spiritual gift to make rain and bless crop and animals.

${ }^{6}$ This folktale is the most widely known oral tradition among the D'irasha
}

just giving a dry grass (Serat). Then fill milk in a container that the cow drinks water from by the date appointed. When the people did according to the advice and brought the cow to the Dha'ama and it urinated milk.

Thirdly, he ordered his people to produce metallic material that reaches the sky. As usual the people went to the elder. By this time he advised them to dig a deep hole, put bamboo arrow there and cover it with the leaf of enset plant (false banana) and mattress in order that the no one can see what is under it. Then arrange everything necessary for making the metallic material with blacksmith in wider space in front of the hole. After that, invite the Dha'ama to seat on the mattress, with great honor, to observe how they are committed to fulfill his order to produce the material. Finally, when he falls in to the hole, fill it with soil and bury him there. The people did accordingly it became the end of the ruthless Dha'ama Ka'ana.

The folk explains the position eldership among the D'irasha (Many of African societies in general) as it is inherently linked to wisdom acquired through experience and the assumption that paying attention to elders as a source of the maintenance of the wellbeing of the society in general and its individual members in particular. It also shows how dictatorship or absolutism was rejected in pre-colonial sociopolitical systems. Elders guide their people on how to get out when rulers act against the existing norms, customs and traditions without the consent of their people. Even today, significant portion of the community pays attention to elders than anybody. Therefore, in African context elders are genuine representatives of the interest of the community. Popular power is exercised through the reflection of people's interest by elders. The disregard to the customary role of elders in the political life of the community is viewed as a path to dictatorship as it was seen in the folk of $\mathrm{Ka}$ 'ana. Now days, however, this essence is seriously challenged by the intervention state and non-state actors to manipulate the voice of elders for the fulfillment of their interest. The social crisis observed in rural communities of Africa is the implication of the disregard to these values.

The D'irasha tradition tells, after the death of Dha'ama $K a$ 'ana, there was a vacuum in the indigenous socio-political system, especially the office of the "rain maker". This was a period without "rainmaker". As a result it is believed that the people suffered from drought until the coming of the Titiba family. It is thought that the Titiba family first moved from a place called Sabar (most probably an area along the borders of the Somali and Borena) to Konso (Karate) passing through Liben. In the family there were two brothers with special spiritual gift (Saga, as the people refer to it). The two brothers were named Kalla and Fella. The family had settled at Konso-Karate for a certain period of time where disagreement arose between the two brothers. After discussing the matter with elders in Karate Fella and Kalla agreed "to speak to the land of Konso and to whom the land responds shall stay there and the other will leave". According to the tradition Kalla was very wise and hidden a 
woman in a cave that he had prepared early in order to win the game.

In the date appointed by elders, both came "to speak to the land". The first chance was given to Fella and there was no response. When Kalla spoke, however, the women he had hidden in the cave responded. Fella left Konso as a loser of the game. As soon as he left, however, a heavy rain with threatening lightning occurred. This was understood as a wrath from the spirit of Fella who was very angry by the situation. Thus people were ordered to build a house and asked him to return. However, their quest as not accepted by Fella who was already at a distance place called Mashole by then.

On the other hand, the incident was heard among the D'irasha where there was a vacuum in the position of the "rainmaker". Elders of the D'irasha sent Hella (the youth) to Mashole to bring Fella to their land. Fella and the people with him accepted the Hella and agreed to come to D'irashe. After leaving Mashole, the Titiba family settled at a hill called Hoyba Tullu which is found in Siltoya of Yaybe in D'irashe. From there they moved to the top of Horoma Qallo (Gardulla) ${ }^{(7)}$

Tililo is a place where many springs of water on Gardulla. Locally the springs were referred Ayladha to mean sacred water. It was a dwelling place for different sprits linked with rain making rituals. Especially when the rain refuses to come through the usual rituals during drought seasons, the Dha'ama stays at Tililo for seven day. Later (around 1920s) the head quarter of the Dha'ama shifted to Korkora near the marvelous water fall of Hitawe River. Because of the importance of "sacred water" in rain making rituals, historically the locations of the headquarters of the Dha'ama were related to rivers, water falls, springs and the like.

The Titiba family of the Kolayta clan arrived to D'irashe around $16^{\text {th }} \mathrm{c}$. There were also other clans who were believed to have come from Sabar like the Titiba and entered in to D'irashe through Kore/Amaro (Hoyera). These include the Argamayta clan who were led by Kittee and who had settled at Maleka of Tarkale and the Kalayta clan who were led by Kosha and settled at Nagulo of Kandhile. The Kansita clan also believed to have come from Borena, first to Mossie (Bussa) and later migrated to D'irashe under the leadership of the two brothers Alkite Tibane and Alkite Bukeno. Members of the Mallita clan as well claim to have come from Borena. The D'irasha asserts that among the nine clans five of them (Kolayta, Argamayta, Kalayta, Kansita and Mallita) claim to be migrants from around Borena. Among the remaining four, while the Aelayta claim to be there since time immemorial (qandha husat); the Karita connect their origin with Abba Roba in Borena. With regard to the Ketaya (assumed to be branches of the Mallita) and the Karchita there is no clear data. However, today, the D'irasha exhibit

\footnotetext{
${ }^{7}$ Horma Qallo is the local name of a mountain known today Gardulla. It was named Gardulla since the coming of the Abyssinians towards the end of $19^{\text {th }} \mathrm{c}$. The Abyssinians also established garrison town on the top called "Gardulla Ketema"
}

single and relatively uniform ethnic identity regardless of claiming different origin. The symbol of their unity was the "rainmaker" the Dha'ama, who was the nucleus of their indigenous socio-political system ${ }^{(8)}$ (Black, 1973, Hansamo, 1983, Gravas, 1997).

Table 1. The nine clans of D'irasha and origins they claim.

\begin{tabular}{llllll}
\hline No & Clan & Origin & No & Clan & Origin \\
\hline 1 & Kolayat & Sabar/Liben & 6 & Kansit & Borena \\
2 & Kalayt & Liben & 7 & Malit & Borena \\
3 & Arkamayt & Liben & 8 & Ketaye & Unknown \\
4 & Elayt & Derashe/Qandha & 9 & Karit & Unknown \\
5 & Karchit (Esalayt) & Unknown & & & \\
\hline
\end{tabular}

After coming to D'irashe, the Titiba family gained special status among the nine clans of D'irasha. This was because of the rainmaking gift and their ability to bless crops and animals. They also came with the seed of sorghum which became staple crop replacing Ka'ata among the D'irasha till today (Hansamo, 1983 and 2001). Dha'amuma formally shifted from the Elayta clan to the Kolayta and this was the time when the D'irasha indigenous political system began to be institutionalized.

\subsection{The Pre-conquest Socio-political System of the D'irasha}

The D'irasha who had developed political institution of governance since $16^{\text {th }} \mathrm{c}$, suffered from the imposition of alien systems since the Abyssinian conquest of 1890s (Gravas, 1997 and Hansamo 2001). This system share common characteristic features with many of the pre-colonial African indigenous institutions of governance. Neighborhoods, villages, clans, etc...were central elements of political and social organizations.

Qayetum (neighborhood): is the basic element of the D'irasha indigenous governance system. The tradition of working together and participating in social issues at the neighborhood level is called qayetum. The people have a proverb saying "a neighbor comes before kin during trouble".

Suga: Suga was a person who holds hereditary politicoreligious position as an agent of Dha'ama at a neighbor level (Hansamo, 1983). He was responsible to coordinate member of a neighbors and settle disputes with elders. He also ensures the fulfillment of annual gift to Dha'ama.

Appa Timba: (man of the drum), was an elect of people at a neighbor level. He facilitates and mobilizes the people for social events like mourning, illness, accident etc... His main task was to call the people for meeting and other social gatherings.

Village ( $\mathrm{Pa}$ 'at)

The pattern of settlement among the D'irasha is not based on clan. People might be identified with their village ( $p a$ 'at) in addition to their clan. For example, during hunting or traditional games, people express their emotions by calling

\footnotetext{
${ }^{8}$ Hansamo who studied the D'irasha Culture associates the movement of the clans with the Oromo population movement of $16^{\text {th }} \mathrm{c}$. Black also linguistically described the D'irasha language to be originated from the Oromo language.
} 
the village they belong: tibanena! alkayena! Tarkalena! There were also villages with special role in the governance systems. For example, Kantikama was a village responsible for defense or execution of decision the court of elders by force. That is why they were called Kantikama kamantarba! It implies "their foot is like that of the elephant!"

Shana: was a village priest with a hereditary position responsible for village based religious rituals. Annual gift of Dha'ama collected at the neighborhood passes through him. He also performs some sacrificial rituals on behalf of the Dha'ama.

Maka: was an elder elected for administrative matters at the village level. He was responsible for coordinating the people for free labor for the farm land of the Dha'ama and settling disputes that are not solved at the neighborhood level.

\section{District (Shella)}

Shella was hereditary but the holder was a person with special gift or sag to protect the D'irasha and their crops and animals from disease, and other dangerous. Its spiritual function was all over the people, but its administrative role was limited to the district. Hierarchically it was next to Dha'ama; however, in few cases they were referred as Dha'ama's of their respective district. For example, people say "Kittee, Dha'am Kittolat!" Shella is also head or Poldha for his respective clan.

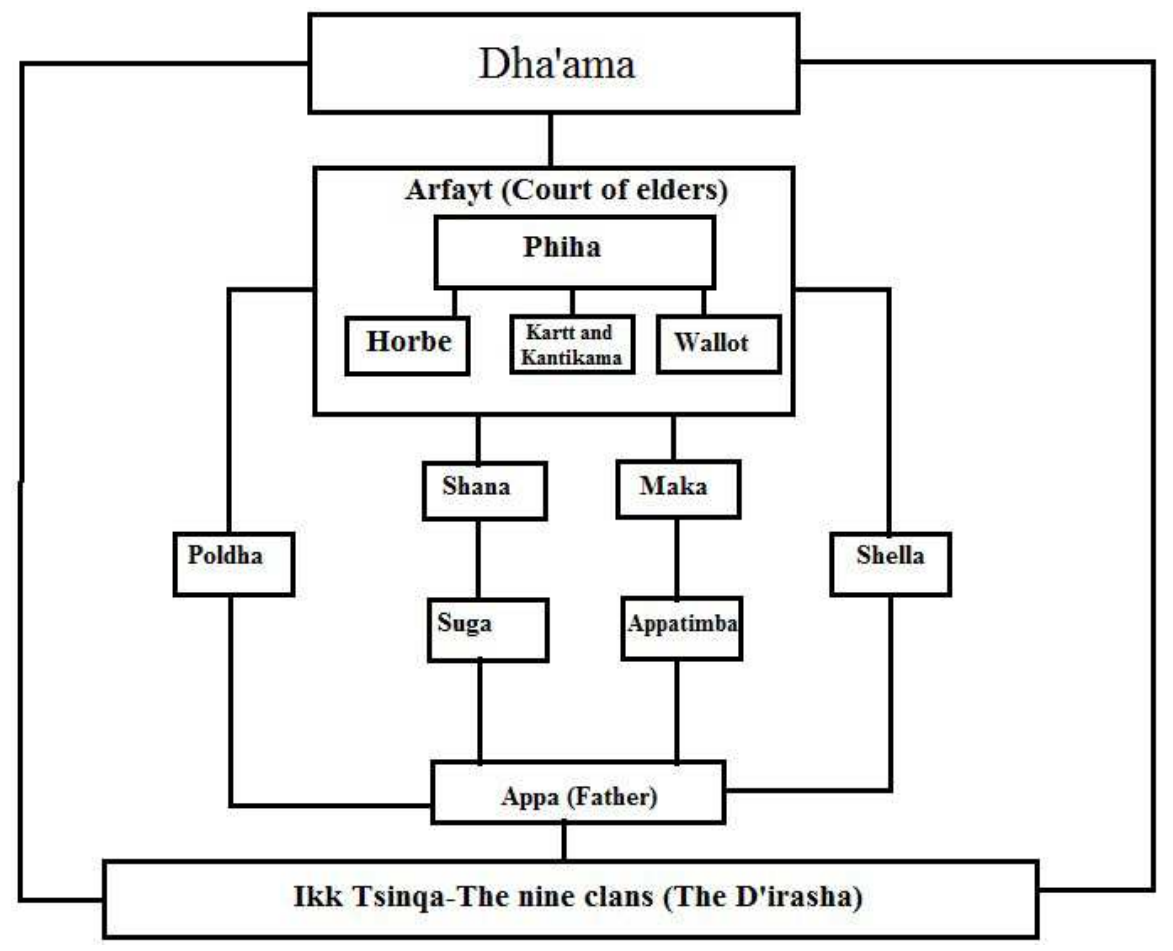

Figure 1. The structure of indigenous socio-political system of the D'irasha.

The Rain maker: Dha'ama

Dha'ama is the politico-religious father and the only rain maker in the land. Before the coming of the Italians the seat of the rain maker was located at the highest topographical point in D'irashe, on the top of Mt. Horma Qallo (Gardulla) which was at $2600 \mathrm{~m}$ above sea level. His political status is controversial among the very few scholars who have mentioned the D'irasha. Hansamo cited a western writer named Busk who had mentioned Dha'ama as a "king of D'irasha" (2001). Cerulli on the other hand stated about the special burial style for "a king" with the title "poqalla" in Gidole [D'irasha]. "Poqalla" is in fact, a Konso title for clan

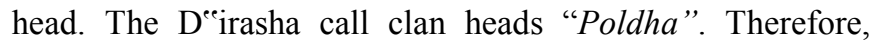
Ceruli might have misplaced the terms. Whatever the case, he mentioned "Poqalla in Gidole [D"irashe] as "a king" (1956). However, Dha'ama is not king or he doesn't fulfill characteristics of a king, especially in terms of exercising political authority over his people. He is like spiritual father than a ruler. His roles are largely confined to blessing crops and animals; and making rain. This made him to be strongly linked to fertility and continuity of life. That is why the Dha'ama is viewed as a father of the people and symbol of their unity.

Dha'ama was also the only person among the people to uses a black ring called Michira and a bracelet called Hauratota. These materials were made from bronze and symbolize the supremacy the Dha'ama all over the land. In addition to this, in the past, anyone who had killed a leopard or an elephant in D'irashe territory was expected to bring its leather ivory to the royal court. He can only make it personal property by the good will of the Dha'ama (Gravas, 1997 and Hansamo, 2001). This shows the extent of territorial jurisdiction exercised. In addition, till today, it is only on the houses of the Dha'ama and other respected entities belonging to his clan, Kolayata, like Kania, that the egg of an ostrich is placed on the top their houses on the Mashawata (cape like material made of clay placed on the hats).

Dha'ama of the D'irasha is also Poldha for his respective 
clan, Kolayta. The symbol or totem of the clan is "land" and "cow". It is only members of this clan that can swear in land. When the D'irasha people call land with respect and honor they say Titibaytet "sacred land". The family to whom the Dha'ama belongs is called Ob Titiba. Whiles swearing, any member of the Kolayta clan says Titibaya! Some conservative elders till today while they pray before meal, they repeatedly mention the term Titiba with the names of other ancestors next to Moha [the sky God].

Until 1975, the 27 Dha'ama's (From Fella to Sama II) had have never married from the D'irasha based on the assumption that the D'irasha are his children. He marries from neighboring communities mainly from Zayse, Kore and Mossie. This can also be explained as a political marriage for military alliance and a voidance inter-ethnic conflict.

According to the tradition the Dha'ama marries two or three "ordinary" wives before marrying the actual Ha'eta (queen). It is from the Ha'eta that the heir (the rainmaker) would be gained. If he marries the Ha'eta early, she may deliver the heir and two rain makers cannot live together. The former will die. Therefore, Dha'ama marries the Ha'eta lately. With regard to the way the Ha'eta is identified the tradition dictates:

"Laysho" (shooting star) is the messenger Dha'ama. One of its duties is indicating where the women to be the Ha'e ta reside. The elders follow the directions of the star and identify where she is. The women to be Ha'eta notice unfamiliar character since her birth. For example, water may come out when she scratches the soil. Therefore, their parents will suspect their daughter might be queen for a certain king. Elders guided by "laysho" will send messengers to her residence. "(9)

With regard to succession, even though, Dhamuma is a hereditary position it is not just the first born son who succeeds the position. The tradition asserts that among the sons of the Dha'ama the one who becomes rain make res identified by a piece of sorghum in his hand during birth or other miracle he can perform.

The Court of Elders: Arfayta

Since the Dha'ama is more symbolical than real, the political function among the D'irasha is handled by the court of elders called Arfayta. Members of the court were chosen from among the people on the bases of their passion to the values, customs, and traditions of the society (Hansamo, 2001). The court had seven members who were end owed with the wisdom of judgment attained through experience. They were chosen by the Dha'ama under the guidance of his personal advisors (Solawa). The major role of the court is to maintain peaceful co-existence of the community in accordance with customs and values. The day to day religious and administrative matters were handled through offices at the neighbor, village and district level by the suga and shella. Therefore, cases presented to the Arfayta are those which were very serious and assumed to have the

\footnotetext{
${ }^{9}$ This information is obtained from Kusia Tolonge in 2012
}

capacity to dismantle the socio-political and spiritual wellbeing of the D'irasha as a whole. It was like the Supreme Court of the "modern" concept of western constitutionalism.

Theoretically, the position of Dha'ama was above the Arfayta. However, he was not expected to attend all trials. Every decision of the Arfayta was considered as the decision of the Dha'ama. The court was chaired by the chief priest of the Dha'ama called Pihha. The Pihha was the key agent of the Dha'ama especially on religious matters. Dha'ama is protected from ordinary matters based on the assumption it may affect his sanctity and he may lose the rain making gift. Therefore, he had to keep himself a way from "ordinary" matters. The relation between the Dha'ama and the Arfayta was bridged by the Pihha"

Never the less, when the case requires capital punishment like death penalty or dismantling a house of an offender, the Dha'ama attends the trial in person. In fact here also his presence is symbolical. He speaks through the Pihha. This shows how D'irasha system avoids autocracy and unilateral exercise of power by individuals. Power resides in the hand of the Arfayta under the fatherhood of the Dha'ama. It was like African variety of the western parliamentary constitutional monarchy where "popular sovereignty" is manifested through elected representatives.

Offices around the courtyard of Dha'ama

Pihha: - was a hereditary position of chief priest. He was a bridge between the court of elders and Dha'ama. He attends the usual meetings of the court and communicates other offices who were responsible to execute decisions. He was like spokesperson for the Dha'ama.

Horbe: - was a position responsible to check whether the decisions of the court were fully executed or not. He usually communicates clan heads (poldha"s) to check their members are observing the law. He follows execution of the sanctions or compensations imposed up on individuals through clan heads.

Wallota or Makiya: Chiefs funeral performers. Formerly every clan had its own funeral performers. These people were known as Wallotaor Makiya. They were also responsible to conduct special rituals during the death of Dha'ama and perform his funeral according to the tradition.

Kartta and Kantikama: the Militia or the Police.

Kartta is actually a village located to the north the Korkora seat of the Dha'ama. The residents of this village were guardians of the royal court. They also execute decisions of the, Arfyata. For example, the tree up on which death penalty is performed (qoyer homboltat) was located in this village. The militia in this village was led by a family in the Kolayta called Ob Kania.

Kantikama on the other hand, was a village where the militias responsible for the defense of the D'irasha. It is found in southern part of D'irashe. While the role of the Kartta was like "police and imperial body guard", the role of the Kantikama was like "defense force". However, there were cases when their role over laps. The Kania also had the authority to intervene and "dissolve" the Arfayta when it acts against the established norms and traditions. 


\section{Clan Based Offices}

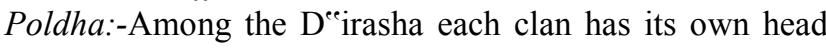
called Poldha. One clan has only one key Poldha (the eldest from the Poldha family) and many other sub-Poldhas. Therefore, there are nine key Poldha's throughout D'irashe. The position of Poldha is hereditary usually passing to the first born son with the exception of the Dha'ama's clan. (Even though Dha'ama is Poldha for his clan he might not be necessarily succeeded by his first born son) Poldha is like spiritual father of members of his clan. His religious role was mainly manifested through annual ritual conducted in his compound to pray for the well-being of members of the clan. This ritual was attended by all sub-Poldhas in the compound of the key Poldha and later conducted in the irrespective villages and at the family level. It was a prayer to protect the whole clan from disease and other manmade and natural catastrophe. The ceremony was called gnerga. Gnerga was conducted by calling spirits of ancestors and splashing sanctification blood on the deity of the clan. Administratively, Poldha is the one who communicates the Arfayta through Horbe on behalf of the clan. He may represent any individual member of the clan in front of the Arfyata. He mobilizes members of the clan to contribute compensation imposed on individual member of the clan as a punishment for doing wrong.

Anfatot: - clan priest. Every clan had its own priest who is responsible for religious matters of the clan under the fatherhood of the Poldha. Anfatota guides the Poldha in the annual ritual and other spiritual matters. In most cases Poldha is passive and the Anfatota actively regulates activities.

Kadhaya:-In every village there are agents of the Plodha which are called Kadhaya. They serve as representatives of Poldha in their respective village. Any clan related matter at a village level should pass through them before reaching Poldha. They also handle simple cases that can be settled at village level with elders. In most cases Kadhaya's were subPoldha or brothers and other relatives of the key Poldha residing in different villages.

\subsection{The Abyssinian Conquest, the Beginning of the Collapse}

The territory of the D'irasha was incorporated to the Ethiopian empire in 1890s. During this time there was no Dha'ama who can lead the people. This was because of the death of 23rd Dha" ama, Sama I, without heir to his position. However, his wife Sasike, who was from the Kerdhifa family of Mossie mobilized the combined force of D'irasha and Mossie for defense. However, the area was easily conquered because of the military upper hand of the Abyssinians. In the early days of the conquest the Abyssinians enslaved the youngest population totally. This was a period when the D'irasha provided their children for slavery in the form of tribute for their new rulers (Hansamo, 1983). When Fitawrari Wolde was appointed to govern Borana Territory on behalf of Fitawrari Habte Giorgis from Gardulla Ketema around 1900 (Oscar, 1902 and Hudson, 1970), he came up with another phase of exploitation which was relatively moderate than his predecessors. ${ }^{(10)}$

For the realization of the new approach he converted the $24^{\text {th }}$ Dha'ama of D'irasha, Talto, to the Orthodox faith through baptism with a Christian name Wolde Aregay. Besides, he was circumcised contrary to the existing tradition his people. Subsequently he was designated Balabat, an Abyssinian title provided him with new power mainly collecting tribute from his own people (notthe Abyssinian settlers) on behalf of the state. According to the Abyssinian feudal system, "Balabat" was indigenous leader of the people exercising power as a local agent of the Abyssinian governor or owner of the territory (the bale rist) (Hansamo2001).

During this time, while the Dha'ama was made Balabat, other key offices of the indigenous system like Shella and Poldha were made collectors of tribute on his behalf and facilitators of free labor to the state dignitaries, the neftegna. As a Balabat, the Dha'ama in turn provides the tribute to the Abyssinian governor. However, the offices of Dha'ama, Shella and key-Poldha were exempted from providing free labor. But they were not free from paying tribute in cash or in kind like any other D'irasha (Hansamo2001).

This Abyssinian policy find direct rule was more or less similar to how the colonialists transformed African traditional system for their interest and was their stereos challenge that the in digamous socio-political system of the D'irasha had faced. In fact spiritual aspects of the system, mainly the rituals of making rain and blessing crops and animals were maintained. But, the people started to lose confidence on their Dha'ama, especially his conversion through baptism and circumcision made him to be viewed as eunuch of the Abyssinians. As a result, the court of elders secretly planned to separate the indigenous Dha'amuma from the newly introduced Balabat. Fortunately, however, Talto died without successor. The death of Talto was considered as a punishment by Moha (sky God) for breaking the tradition in accepting new religion and circumcision. This was a good ground for the conservative elders who had secretly arranged a marriage between the widow, Sasike and Koona from $\mathrm{Ob}$ Korkora family which was a well-known from the Kolayta clan. The tradition allows a widow to marry a brother or close relative of her ex-husband. Such marriage was called Dhahala. Children acquired from such marriage were considered as children of the ex-husband. Luckily, Sasike gave birth to three sons following the secret marriage arranged by the conservative elders. The sons were named Shagro, Kayato and Sayle born respectively. Among them, Style was told to have born with a piece of sorghum in his hand that makes him hegira parent of the rain making office according to the tradition. However, something very unusual happened while the effort to have unbaptized and uncircumcised Dha'ama was going on. This was the request

\footnotetext{
${ }^{10}$ The territory in southwestern Ethiopia including D'irashe, Konso, Borena and Parts of South Omo was a fief of war minister of Menelik II Fitawrari Habte Giorgis. The Province was called Borena Territory with headquarter at Gardulla Ketema till 1936.
} 
by Dhatona, the eldest daughter of Talto, to succeed the position of her father. Dhatona was converted with her father and given a Christian name Wolete Tsadiqe. After baptism she was taken to Addis Ababa by her God mother and attended church education. She was also married from among the outsiders. After the death of her father; however, she divorced her husband and requested the position of her father. She might have been inspired by empress Zewditu (r.19161930) who was ruling Ethiopia by then (Bahru, 1991). Nevertheless, her request was rejected by the court of elders. Dhatona took the case to the Imperial court in Addis Ababa. The verdict was for Dhatona to inherit the Abyssinian title, Balabat and left the issue of the office of the Dha'amuma undecided. This was an opportunity for the conservative group to separate the two offices. Therefore, they inaugurated Style to the indigenous title Dha'amuma. While Dhatona was serving as an agent for the Ethiopian empire, the majority of the people adhered to their indigenous institutions for judicial and spiritual affairs. As a result, a kind of dual political elite began to emerge and rally around both the "progressive Balabat Dhatona" and the conservative Arfayta and Dha'ama. In this rally, while the progressive group was backed by the Abyssinian ruling elite, the Ethiopian Orthodox Church and the settlers, the fate of the conservatives was at the will of the mass of the D'irasha. It was in this situation that Italian occupation occurred in1936.

\subsection{The Brief Italian Occupation - Survival and Continuity}

At the beginning the colonial army of the Italians was viewed by the majority of the D'irasha as a liberator from the Abyssinian political and cultural hegemony. The conservative groups used this opportunity by giving recognition to the Italians. They took Sama II (who was heir of Sayle and 6 years old by then) to Gumayde Italian military base a sign of surrendering. After conquering Gardulla Ketema, the Italian arrested key members of the Abyssinian ruling elite including Dhatona and took them to Filtu colonial prison in Borena. They also recognized SamaII both as a Balabat and as Dha'ama of the D'irasha. This was done to easily win the support of the mass and mobilize them for their colonial mission. They also gave SamaII the Abyssinian title, Grazmach. Very soon, however, they started to collect tribute from the people. In addition, after shifting the town from Gardulla Ketema to Gidole, they started to force people to provide free labor for construction of administrative and residential buildings. A road network for the colonial administration connecting Yabelo, Gidole and Chencha was built by forced labor provided mainly by the D'irasha. The Italians who were viewed as liberators later became very harsh. The traditional system also remained symbolical. The brief Italian period which came to an end in 1941 also suffered from the repeated guerrilla attack from the Abyssinian Patriotic resistance. Dhatona, who escaped from the prison in 1938, also joined the resistance. In the middle the people suffered both from the forced labor of the Italians and the sudden attacks and lootings of the patriotic resistance (Hansamo, 2001).
The early years after the evacuation the Italians (1941) were relatively times of relief to the local people. The feudal exploitation system was not reinstituted immediately. Later, however, the Abyssinians came up with a new tactic of sustaining their hegemony. This was massive conversion of local people to the Ethiopian Orthodox Christianity. One of my informants described this situation as follows:

"We were taken to the place where St. George Church is found today. They baptized all of us and placed a thread on our necks. We were told, "Now onwards everyone is equal. No difference between Qatar [the Abyssinians] and D'irasha". They also thought us to observe fasting days and not to work on Sundays. It was very difficult for us to learn all these. A police was assigned to Control people going to their far moon Sundays".

This conversion and baptism mainly targeted key personalities in the in digamous system like the Dha'ama, Shella and Poldha. However, its implication was minimal on the cultural life of the people. They were free to exercise their tradition. Towards the last years of 1940s however, the struggle between the two groups revived. After the death of Dhatona in 1947 her sister, BirqeW/Aregay, claimed the Balabat title. When local officials failed to respond she took the case to a Provincial court at Chencha and succeeded to take the title. Grazmach SamaII, who was both Balabat and Dha'ama until then, was left with the traditional title.

\subsection{The Coming Missionaries -Breaking the Backbone of the System}

However, the most serious challenge to the indigenous system of D'irasha came after 1950. This was the coming of protestant missionaries (Gravas, 1997). At this time the central government of the Abyssinian Empire recovered and reinstituted its institutions of exploitation. The peasants also started to pay tribute to the new officials who had come with new titles based on their patriotic contributions. On the other hand, inspired by the lucrative commercial agriculture began in a nearby by Zayse low land, Abyssinian élites began to claim the D'irashe low land as their rist. ${ }^{(11)}$ It was during such a terrible exploitation that the protestant missionaries came to D'irashe in 1951. As part of his modernization project, Haile Sellassie I (r.1930-1974) allowed missionaries to evangelize people in southern Ethiopia as far as they have provided education and health care services (Hansamo, 2001). In the early days of their coming, however, it was difficult to find converts from among the D'irasha. However, after they started to provide health and education services they were able to find few. Gradually the people started to view their activities as a relief from Abyssinian pressure of exploitation.

In 1960 the missionaries succeeded in mass conversion. Their evangelization targeted at the core element of the indigenous system. They boldly preached "it is God who

\footnotetext{
${ }^{11}$ According the Abyssinian land holding system rist is defined as a plot of land owned by a person that transferred to other person through sale, mortgage or gift.
} 
gives rain not the Dha'ama”. Rainmaking rituals and other traditional spiritual practices were labeled as evil works of devil. The conversion gradually led to the emergence of new class among the D'irasha detached from the rain makerDha'ama and his institutions (Gravas, 1997). However, the success behind the missionary activity was not just the sympathy of the people to the evangelical teachings of the missionaries. Rather it had political implication in showing how the D'irasha people rejected the Abyssinian cultural and religious hegemony. This was in fact reflected in the rapid shift of the people from protestant Christianity to socialism in1974. They immediately turned the local Chapels and Prayer Houses to administrative offices of the socialist regime, because, the 1974 revolution attacked and completely destroyed the Abyssinian institutions of exploitation. This was what the Norwegian missionaries can't do. They preached the freedom in the heavenly world to come while the people were still under the cultural and political dominion of the Abyssinians.

\subsection{The Socialist Revolution in Ethiopia- the Final Collapse}

The revolution of 1974 came up with a paradigm shift in the struggle for survival of the indigenous socio-political system of D'irasha. The declaration of the policy of "land to the tiller" highly satisfied the mass who already lost their lands to Dejazmach Taddesse after the decision of the Imperial court in 1972. This makes it mandatory to accept the revolutionary government with their full hearts. The Norwegian easily introduced its bureaucracy to the grass root level through peasant associations. This regime did what both the missionaries and the indigenous system failed to do. Therefore, the people rejected both and this became the most serious challenge to the indigenous system.

Between 1974 and 1976, when properties and land of the feudal lords including public institutions were made under the control of the D'irasha revolutionary elite, the indigenous institutions of Dha'ama, Shella and Poldha remained untouched in most cases. Nevertheless, after the coming of students for the campaign launched at the national level, Ye'edget Be'hibret Zemecha, attacking indigenous institutions began. Leaders of the campaign mobilized the mass convincing them that both the Abyssinian and indigenous systems have to be destroyed to realize the new order in its fullest form. Especially local cultural values and practices were portrayed as hindrances of progress and transformation. The destruction project targeted deities, royal courts, sacred forests and other symbols of the indigenous system.

The death Dha'ama Sama II in July 1976 marked the level the inherent attachment of indigenous system to the sociopolitical life the people. Even after half century destruction by different agents and while the revolutionary campaign was taking place by targeting the systems, the people responded to the death of their "rain maker" was unexpected manner. One of my informants during my filed work in 2011 described the situation as follows:-
“It seems no D'irasha was left at home. All people except members of the Kolyata clan removed their hair. According to the tradition no one came out with Jewelry. No one was allowed to exchange commodities in markets, especially crops. People were coming in group from different directions. They expressed every deep of sorrow. In accordance with the tradition, when residents of the Tackle blew tarba (a horn) all people who came in different direction laid down on the ground. When the tarba was blown for the second time all males knock the earth with their leg. It really seems earth quake”.

The event marked extent of the concern of the people to their tradition. It was an event that brought the whole D'irasha together regardless of religious and other forms of differences. Another informant, who does not belong to the D'irasha, stated the event as follows:

"No one was allowed to sale crops. Open shops were looted. No one can move without binger moved his hair. The way the people manipulate their spear was threatening. Even, the Zemach students who had been mobilizing the people to destroy "sacred places" feared and removed their hair to save their lives".

However, after the funeral of Sama II according to the tradition, the situation was not suitable to in augur tea new Dha'ama publicly. Since the revolutionary regime saw indigenous system as a hindrance of the emancipation of the people. Consequently, coming with annual gift and providing free labor to the Dha'ama was outlawed. Therefore, the secretly initiated successor of SamaII, Jimiru escaped to Arbaminch, a town 50Km away, in1977. Since he had lost the customary privilege, he started to make a living from carpentry. However, conservative people continued to bring their annual gift of a new harvest and visiting his ho use in Arbaminch. The intensity of the visit increases during drought seasons based on the assumption that it is an outcome of not fulfilling what is required from the people to the Dha'ama.

\subsection{The post 1991 Era of Federalism}

The year 1991 marked radical change in the political landscape of Ethiopia. Self-determination became core principle of politics. During the Transitional Period (1991194) the political elite of the D'irasha involved in a political movements as part of North Omo Administrative Region. Kengalew Halle, D'irasha elite, was one of the leading people during this time. However, other D'irasha elites who were living in Arbaminch were not satisfied with situation and started secret movement under the leadership of Yonas Roba and Taffese Walesa. This people came up with the idea of having separate political party representing the D'irasha. Finally a political organization named D'irasha People Democratic Organization (DPDO) was established and registered as the $18^{\text {th }} \mathrm{c}$ political party of Southern Ethiopia by the National Electoral Board in 1994. The point here was the involvement of Jimiru (the Dha'ama) in the initiative of establishing the political party. He was encouraged to involve because of the principle of self- 
determination that has become core element of the politics of the transitional period (1991-1995). It was expected that the new political order will at least integrate indigenous systems to local governance.

It was based on this assumption that after the establishment of DPDO in 1994, Yonas Roba and Jimiru came to Gidole in order to promote their political program and mobilize the D'irasha. However, the move was odd and strange to the Abyssinized D'irasha elite and the urban dwellers who preferred to be called Gardulla than D'irasha. In fact there were people who appreciated the idea. Therefore, Yonas and Jimiru were forced to return to Arbaminch. Later, however, when the southern region of Ethiopia came us one of the federating units of Ethiopia, DPDO emerged promptly with D'irashe Liu Woreda as one of the Special Districts in the Regional State.

However, even after the promulgation of the 1995 constitution, self-determination was interpreted in a way that makes politics a game to be played only by the educated elite rejecting cultural values and indigenous systems. The rural community was needed only for election. Governance was modeled after the western style of representative majority rule as opposed to the participatory consensus oriented African essence of democracy (Baba, 2014).

\section{Conclusion}

The D'irasha people who are one of the indigenous communities in the horn of Africa, residing in south western Ethiopia, suffered from the conquest and hegemony of the Abyssinian Empire of Ethiopia. Their indigenous sociopolitical values gradually deteriorated and even finally collapsed mainly because the conquest and as a result subsequent internal and external interventions. The federal system with its promises of self-determination and selfgovernance also failed to contribute to the revival and continuity of the indigenous system because of its preference to the western elite based system for local governance. Further study is expected from researchers regarding mechanisms of revival and re-instituting indigenous socio- political values for community development, for ecological advantages, for peaceful co-existence, social cohesion and continuity of D'irasha identity.

\section{References}

[1] Asmerom Legesse (2006). Oromo Democracy: Indigenous African Political System. Red Sea Press Inc. Asmara, Eritria.

[2] Bahru Zewde (1991). A History of Modern Ethiopia 18551974: London. James Curry.

[3] Black, Paul (1973). Linguistic Evidence of the Origin of Konsoid Peoples. Proceeding of the first United States Conference on Ethiopian Studies. East Lansing. Michigan State University.

[4] Cerulli, E. (1956). Peoples of Southwestern Ethiopia and its Border Lands. London: International African Institute.

[5] Gravas, Hans, A., (1997). Penetrating the Territory of D'amma: Emic perspective on the Intercultural Encounters and the Emergence of an Indigenous Church among the D'irasha (Gidole) of South Western Ethiopia. PhD Dissertation for the Degree of Doctor of Philosophy at Trinity International University, Deerfield, Illinois June 1997. (Unpublished).

[6] Hallpike C. R., (1972). The Konso of Ethiopia. A Study of the Values of a Cushitic People. Oxford at the Clarendon Press.

[7] Hansamo Hammela (1983). Internal History of D'irasha (Gidole) (Unpublished BA fourth Year Essay, Addis Ababa University)

[8] Hansamo Hammela (2001). In the Custom and Tradition of Southern Ethiopia: History and Culture of D'irasha People. Addis Ababa. Tikur Abay Publishers. (Published in Amharic).

[9] Hudson, W. Arnold (1970). Seven Years in Southern Abyssinia. $2^{\text {nd }}$ ed. Westport, Conn. Negro Universities Press.

[10] Oscar Neumann, (1902). From Somali Coast through Southern Ethiopia to the Sudan. The Geographic Journal: Volum XX No.4, October 1902

[11] Wondwosen Tesfaye, (2006) Aspects of Diraytata Morphology and Syntax. Doctral Thesis at NINU, 2006. Norwegian University of Science and Technology Faculty of Arts. 